\title{
Wines, Bottles, Crises: A Decolonial Perspective on Brazilian Higher Education
}

\section{Vinhos, Garrafas, Crises: uma perspectiva decolonial na educação superior brasileira}

\author{
Clarissa Menezes Jordão* \\ *Universidade Federal do Paraná (UFPR), Curitiba, Paraná / Brasil \\ clarissamjordao@gmail.com \\ https://orcid.org/0000-0003-3558-5603 \\ Juliana Zeggio Martinez** \\ **Universidade Federal do Paraná (UFPR), Curitiba, Paraná / Brasil \\ jumartinez@ufpr.br \\ https://orcid.org/0000-0002-2244-9621
}

\begin{abstract}
This paper looks into specific cases related to the authors' personal reflections and experiences with internationalization. They are analyzed from a decolonial perspective, taking into account the specificities of Brazilian public education. The thematic categories of analysis were: (1) the social aim/ function of higher education, (2) the impact of internationalization processes on higher education, and (3) the myth of a universal language/planetary unity. It is paramount, especially in times of emergency like ours, that we reflect on the formative, social and political role of universities to respond to ontoepistemological crises such as the one we are immersed in at the moment.
\end{abstract}

KEYWORDS: internationalization; public education; language policies; decoloniality; difference.

RESUMO: Este artigo analisa casos específicos relacionados às reflexões e experiências pessoais das autoras com internacionalização. Tais casos são analisados a partir de uma perspectiva decolonial, levando em consideração as especificidades da educação pública brasileira. As categorias temáticas de análise exploradas foram: (1) o objetivo/função social da educação superior, (2) o impacto dos processos de internacionalização na educação superior, e (3) o mito da linguagem como universal/unidade planetária. É fundamental, especialmente em tempos de emergência como o nosso, refletirmos sobre o papel formativo, social e político das universidades para responder a crises ontoepistemológicas como esta em que estamos imersas no momento.

PALAVRAS-CHAVE: internacionalização; educação pública; políticas linguísticas; decolonialidade; diferença. 


\section{Introduction}

The drive to internationalization is one of the marks of contemporary neoliberal practices in education. It is not a coincidence that such drive has become more and more present in higher education worldwide in the last decade or so. Economists, political scientists and multilateral organizations are called in to analyze tendencies, to quantify practices and to measure the quality of schools and universities. As a result, local educational policies have been informed by "global standards" defining who succeeds and who fails in education (BIESTA, 2009). Professors and language scientists are not always part of the public discussion; perhaps because there is no discussion, but a demonstration of an array of statistics and measurable figures instead, based on visible outcomes which ignore or look down on ontoepistemological indicators. Considering such panorama, this text explores some of the dichotomies built by modernity (such as formative/transmissive education; poor/rich countries; superior/inferior universities; us/them) in order to tension the view of such paradigm on education and literacy education as well as to consider alternative perspectives to modernity.

In Brazil, universities have been designing various policies based on different understandings of what internationalization is or could be. Here, language policies have been more recently conceived amidst discussions on internationalization of education. Such policies have been connected, more specifically, to the contemporary concern with internationalizing higher education as well as to a perceived need to respond to the 'age of measurement' in education. One commonality among these policies seems to be that internationalizing can improve the quality of higher education by placing universities at higher positions in national and international rankings, and making them more competitive in the global market. This is to say that an underlying belief guiding such practices is that to be international leads to participating in the global knowledge economy, which would naturally add up to the quality of the services offered by the universities to local and global populations.

In such assumptions, the belief that when a university becomes international it automatically becomes multicultural and plurilingual seems to thrive. Such assumptions and beliefs, or even hopes or desires, constitute the scenario for most of Brazilian higher education language policies, be they officially recognized as policies or not: the frequent inexistence of a written document does not imply a lack of policy. There are many cases in which 
universities have been teaching specific language courses, hiring language instructors, promoting and funding scientific publication in international journals, accepting international language certificates, and privileging languages in their practices without writing it down in documents as policies.

As a consequence, the establishment of a local culture based on those selected languages greatly influences not only previous practices, but also future (written or not) policies. Practices like those do inform the paths and choices involved in formalized language policies, which need to consider issues such as which languages are to be deemed important for international students locally, which should be the language(s) of instruction to local and international students, which language(s) professors should be proficient in, which should be the language(s) for research production and dissemination, which language(s) should be required from administrative staff, what it means to be proficient in each specific context, etc. All of these decisions need to be considered having each university context in mind, for they do impact directly on who is included and/or excluded from policies and practices, as well as who benefits and/or does not benefit from the possibilities the university is offering and privileging.

When considering different alternatives to language policies, unfortunately there is little if any discussion at all about what is understood as language or how it informs our educational and literacy practices. In the scenario of higher education internationalization languages seem, by and large, to be conceived of as objects that exist out there, disembodied tools, autonomous elements that are reified as commodities to be acquired, bought and sold. External to the subject, language is seen as an instrument of access to wealth, power, knowledge and prestige - much valued elements in the global knowledge economy. There seems to be a general belief (if not a desire) that languages (or better still, A common language, i.e. English) could solve all miscommunication among peoples and nations, as well as allow access to prestige and wealth, both symbolic and material, for those who are said to have ownership of this common language.

Against such background, literacy seems to be understood as access to standard language systems (words, grammar rules), and language competence/proficiency seems to imply the control of these systems by the students, or in other words, "A" system, most often than not understood as "the" English language. Once this privileged system is acquired and internalized, the individual would naturally be able to communicate and 
produce knowledge in that language, and thus be able to communicate with other people all over the world who also have acquired the same language competence. Language in this view is conceived as some sort of transparent system of communication, mediating the production of knowledge - a means to an end, a neutral instrument to be owned, acquired, bought and sold. Even when considering English as a global or international language, the assumption is that there is one and the same English language regardless of where it is (or has been) in the world, or which person is producing English, whose history, culture, experience guide each local production of English in specific contact zones (PRATT, 1991). As a consequence, there is also an assumption that people will automatically understand each other as long as they use this supposedly same language, as if meanings were transparent and languages could be disembodied, separated from their situatedness or situations of enunciation (BAKHTIN, 2010).

From this concept of language and literacy as tools for the mind to be able to act on the world, education becomes a matter of access to highquality knowledge produced by those recognized and legitimated as capable of doing so, that is, those on the geopolitical Global North. ${ }^{1}$ Here we are thinking not only of people, but also institutions "born and raised" where "good quality" science is done and "good quality" education is provided. It follows that, in order to produce "good knowledge" one needs to be or go to the Global North, if not actually, at least metaphorically, and reproduce the practices and standards defined by renowned institutions geographically located there. The idea of the Global North as a standard to be reached by non-Global North institutions, scientists, scholars, professors and their students is very much present in common-sensical practices of internationalization.

In this scenario, there is also little or inexistent discussions about why institutions need to be internationalized or why/how local communities could benefit from the internationalization of education. Why should

\footnotetext{
${ }^{1}$ The references here made to Global South and Global North are axiological and ontoepistemological rather than geographical (SOUSA SANTOS, 2010). This means that such terms are not used to refer to specific countries, but to unequal relations of power that position certain values, ontologies and epistemologies, as well as ways of knowing and knowers as superior and more developed (Northern) or inferior and less developed (Southern).
} 
one need to problematize the fascinating possibilities that globalization, especially in the flux of people all over the world, brings to local science and institutions? The logics of globalization implies that globalization leads to development that leads to progress that leads, not necessarily in this order, to evolution and improvement of science, societies, countries, citizens and, of course, education. This neoliberal ethics that stresses a linear progression between contact and development relates to (or stems from) modernity and the logics of colonization, in which the colonizer attempts to hide their violence and destructive intentions behind its intent of "civilizing barbarians" by unselfishly sharing their religion, language and culture. By imposing or, to put it more candidly, teaching the "wildlings" their own values, the colonizers might see themselves as helping the "savages", who are depicted as soulless, cultureless, religionless, knowledgeless beings. Such well-intentioned endeavors are moved by the desire to help the locals become what they are not, that is, human beings. But not just any human being. The colonizer has a very specific kind of human being in mind: one similar to themselves (colonizers), of course, a spit image that is not what it represents, but can only be a simulation of it, an emulation of the subject it should wish to become. Even though perhaps imbued with such benefactor spirit, colonization and neoliberalism walk hand-in-hand to construct lifeless identities on the colonized, projecting themselves as superior and magnanimous over the primitive peoples they purportedly are trying to help.

In such view, there is of course no need to discuss the social role of education in society, for it is a given: education, schools and universities exist in order to promote, for the colonized, the best access possible to the knowledges of the colonizers. That is understood as social justice and a natural consequence of education, since such access implies sharing what one holds as superior expertise, better interpretive procedures, high-quality ways to see, do and be in the world. The aim of education would consequently be to bring uncivilized peoples closer to civilization, to help them become similar to their colonizers and therefore to the stability and wealth projected as the essence of the latter's way of life. If this requires some (or most) to abandon their ancestral beliefs, to silence their own desires, to invisibilize their frustrations, to leave their people's lands and riches behind, to desert their friends and families, those should be consequences worth facing - the necessary sacrifice in the name of civilization. Questions such as worth for whom, or in whose interests, are rarely, if ever, asked (STEIN et al., 2020). 
We believe one can never overemphasize that such ideology (of colonization, modernity, neoliberal globalization and many times of internationalization) attempts at eliminating from the subject their subject condition and to erase the right to existence of everything which is considered different, inferior, primitive, dumb. By doing so, it underlines the desire for stability (difference can only make life unpredictable), homogeneity (if we are all the same and speak the same language then there will be peace and mutual understanding), previsibility, linearity, order. It also justifies ontoepistemic violence on the grounds of building "a greater good". One of the inherent contradictions of such ideology is that this very quest for equality is based on the promotion of sameness as an ideal: here, therefore, equality is based on a purported distribution of the same values and knowledges (the English language among them). However, at the same time it needs to stress difference so that one has something to crave for, that is, similarity. In other words, founded in the superiority of one specific set of values, in this perspective equality can never be reached, or there will be nothing to feel superior about (it is a never-ending cycle).

This contradiction will be the starting point of the next section, where we explore possibilities about how deep crises, such as the one we are facing with the COVID-19 pandemic as we write this article, can teach us lessons we may not want to learn.

\section{Of crises and bottles in education}

We would like to invite you to revisit an image that has been circulating among us in social networks for some time now. It is the image reproduced below, where we can see three black people trying to watch a baseball game. Because they are different heights, they need different size crates in order to reach the top of the fence that separates them from the stadium and stops one of them, the shortest one, from watching the game. It is of course significant that the three of them are black and seem to have been kept outside of the stadium for unknown (but easily guessable) reasons. But it is also telling that the captions read EQUALITY on the side of the picture where the three people are standing on three same-size crates, resulting that the shortest one still cannot see the game; and the image brings the word EQUITY on the other side, where the shortest one is given a higher crate, and the tallest one is given no crate, so the three of them can see the game. 
IMAGE 1 - This 'Equity' picture is actually White Supremacy at work

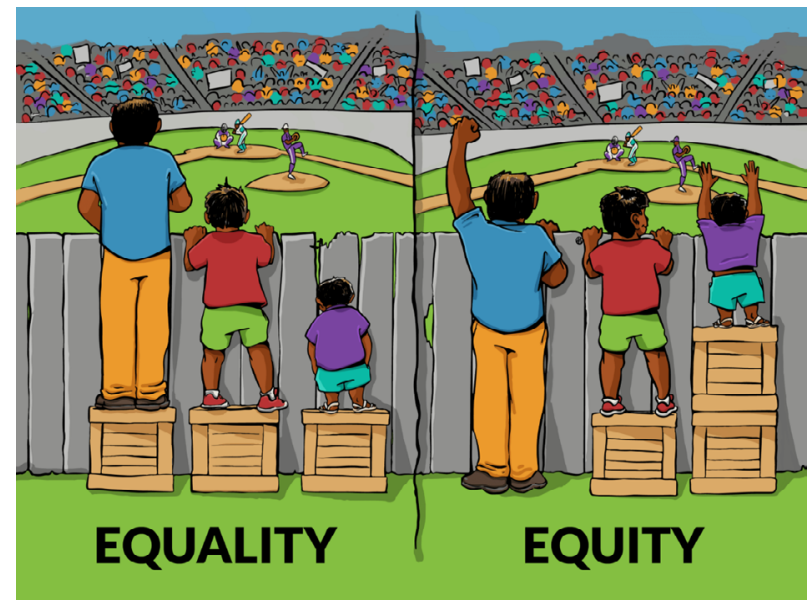

Source: Sippin the EquiTEA. This 'Equity' picture is actually

White Supremacy at work. Nov 27, 2018. Available at: https://medium.com/@ eec/this-equity-picture-is-actually-white-supremacy-at-work-59f4ea700509.

Accessed on: Nov. 17, 2020.

This picture has been widely used by teachers and social workers to demonstrate that the difference between the concepts of equity and equality could be solved within the logic of sameness (guaranteeing access and redistribution) aiming at the erasure of differences. In another direction, the Equity in Education Coalition (2018), analyzing this picture, has shared the view that such perspective exempts the State from the responsibility for both inequity and inequality, stressing individual efforts and downplaying structural constraints to success. For the Coalition, "as useful as the picture was in starting conversations around "Equality vs. Equity," we are basically blaming the individual for being short, black and excluded from the stadium" (Sippin the EquiTEA, 2018).

Such structural discrimination, we believe, has become almost impossible to deny during the COVID-19 world crisis that has been afflicting Pachamama. We have seen the virus affecting everyone, but in different ways: the ones with access to private health care have died in smaller numbers than others with access to public health only or no access at all. Besides, there seems to be greater awareness of our interdependence, not only in terms of countries being constantly connected by mobility and the global market, for example, but also within one country, across social classes: the poorer 
miserable life conditions, without sanitation and clean water, for example, have made it more difficult to maintain hygienic habits so fundamental in controlling the spread of the virus. Are individuals responsible for their lack of resources? Do they lack the will to fight for their rights?

If we go back to the "Equality vs. Equity" image, other questions could be raised: who is responsible for finding the crates? For making them reach the ones who need them? Is each one of us, as individual citizens, part of the (local or global) community, responsible? Are our governments responsible for dumping some of us in deep holes in the ground, in order perhaps for us to become so invisible that no crate will ever make us tall enough? Who is responsible for some of us being inside the stadium, sitting comfortably, while others can hardly see the game? Who is responsible for building a fence that keeps us and them apart? Is there any "blame" in who we are, where we come from or what we look like? What role do our bodies, our histories, our cultures play in all this?

Evidently, we could ask many more questions like these, but we guess these are enough to make our point here: poverty and the unequal distribution of wealth and resources is a very complex issue that needs to be made visible and discussed by individuals, communities and governments. After all, governments and communities alike are made by individuals, here understood not as autonomous beings essentially free, but as people who are made in the intersections among individuals, families, friends, governments, civil society, schools, ideologies, social classes, races, places, to name just a few dimensions of what is constitutive of who we find ourselves to be - or to be in a state of permanent becoming (DELEUZE; GUATTARI, 1997). These dimensions have been made even more explicit with the COVID-19 pandemic that has been exposing poverty, racism, discrimination to the point where it is extremely hard to ignore our collective responsibility as members of the human race towards inequality in the world.

Perhaps it is the very fact that we are facing a global crisis, a moment when everything seems to achieve huge proportions, that has been leading us to ask different questions to old issues such as poverty, hunger, inequality, prejudice, racism, discrimination. Are we trying to fill old bottles with new wine, and running the risk of having the "bottles break, and the wine runneth out, and the [wine]skins perish" (THE BIBLE, 1994)? Old bottles like capitalism and neoliberalism, that have kept our wines for some time now, seem to be breaking, but if our lives will change for the survival of the planet 
or not, it remains to be seen. Boaventura de Sousa Santos (2020) exercises his futurology by predicting three possible post pandemic outcomes: (1) we carry on our routines as if nothing has ever happened; (2) we promote some superficial changes on our lifestyles, such as avoiding crowds and washing our hands more often, or even donating more to the poor, and (3) we move away from neoliberalism into more solidary and collaborative ways of life, caring for the Planet as much as for all that inhabits it.

In terms of knowledge production, more specifically, this third possibility would bring us closer to Sousa Santos' idea of an ecology of knowledges, that is, to the legitimation of different knowledges and different ways of knowing, as well as of the people associated with them. It would not only mean to legitimate and bring to our centers of knowledge production (such as the university) other knowledges besides those constructed from methodologies considered rational and scientific. It would also mean to promote deeper interactions among knowledges from diverse natures and thus produce new ontoepistemologies, even if that means breaking our old bottles and spilling the wine.

Perhaps this should be the main purpose of education: to transgress what has been normalized, to ask new questions, to problematize the establishment, to promote diverse cosmologies with a view at changing the world for the better, for everybody and everything, including the Planet itself. In this regard, Biesta (2009) claims that, rather than discussing the functions of education per se, we should be discussing the kinds of subjectivities it makes possible "as a result of particular educational arrangements and configurations" (p. 41). He posits that the contemporary focus on measuring concrete outcomes of our educational systems and judging the quality of education based on its quantifiable dimensions ends up surpassing what education should be mostly worried about, that is, the kinds of subjectivities it warrants. In his words (BIESTA, 2009, p. 39),

$[w]$ hat is disappearing from the horizon in this process is a recognition that it also matters what pupils and students learn and what they learn it for - that it matters, for example, what kind of citizens they are supposed to become and what kind of democracy this is supposed to bring about [...] - and that, for this reason, education can and in a certain sense even ought to be difficult and challenging rather than that it is just (depicted as) a smooth process which aims to meet the supposed 'needs' of the learner. 
Education is difficult, indeed. Public education perhaps even more so, for in Brazil it means schools are populated by subjects from different social classes, diverse ethnicities, plural gender identities, various religious backgrounds. Public schools are, therefore, privileged spaces for the encounter with difference and for learning how to engage with it. But this is a difficult encounter that brings about its own conflicts, even more so in times of planetary emergencies in various dimensions of our lives, such as health, economics and social structures all over the world. Besides that, since society is permanently under construction, education needs to be also permanently reflexive, ressignifying its "arrangements and configurations" (BIESTA, 2009 , p. 41). This constant movement is way beyond what a neoliberal view of the world is willing to accept in its colonial desire for homogeneity and stability, for orderly progression, predictability, measurability.

Higher education, perhaps more emphatically so than other levels of education, has been subject to neoliberalism and its logic of individualism and personal gain, concrete outcomes and control. This can be seen, for example, from the idea that higher education is bigher than the other instances where formal education takes place: once you reach this superior level you seem to have achieved a superior layer of society that allows you to take control over your life and participate in the global knowledge economy. This is what is generally understood as professional qualification, and perhaps as the main function of higher education: to give students access to sameness, to that one body of knowledge that is to be shared by professional and intellectual elites in the world.

Thus the need to internationalize in order to create sameness, establishing common practices to be shared among different institutions. Internationalization most often implies the implementation of similar language(s) of instruction, similar assessment procedures (of students and staff), similar curriculae, similar language proficiency requirements, similar institutional managements, all of which can be quantified, measured and compared. Considering quality from this perspective leads to the possibility of comparing institutions and individuals, rank-ordering them nationally and internationally. Higher education institutions that function in this logic, therefore, integrate a superior body of institutions responsible for gatekeeping access to the knowledges and ways of knowing considered to be of higher quality. 
Joining such a group of institutions brings prestige but also limits the possibilities for creating different arrangements and configurations and catering for local praxes: although there is no explicit list of rules to be followed in order to remain in this group, such "franchise-like culture" many times works as an illustrious straight-jacket. Institutions are pictured as self-sustained entities and individuals as autonomous beings governed by freewill. This creates a conundrum for internationalization: on the one hand, institutions and individuals strive for being part of the global knowledge economy and the prestige such position brings; on the other hand, in order to remain in such economy they have to subject to external control over the possibilities they envisage within their local knowledge economies.

As we have seen so far, higher education and internationalization are entangled in the discourses of modernity. They coopt colonial violences still present in our lives, reinforcing the coloniality of discourses and practices such as the desire for sameness, homogeneity, measurement and international control. In this desire there seems to be a never-ending search for equality that assumes we should all be equal, in the sense that we should all end up being and doing the same; it assumes that education should guarantee equity, that is, it should provide access to schooling, an access which would, as a matter of course, bring better life conditions to everyone.

In order to further discuss how education (including higher education) and internationalization intertwine with the discourses of modernity, the next part of this text is dedicated to a reflection on educational praxes based on processes of internationalization of higher education in Brazilian public universities. It is from the standpoint of language teacher educators working at university level that we will focus our gaze on three situations experienced by us, that we are here referring to as our vignettes. These experiences taught us about difference, erasures, silencing or, in other words, ontoepistemic violence we witnessed in some of the different contexts of internationalization we have been in the last few years.

Our readings of such situations/vignettes are very much informed by the area of literacy studies, especially as formulated by Brazilian scholars such as Jordão (2011, 2014, 2015), Duboc and Ferraz (2018), Menezes de Souza (2011a, 2011b), Monte Mór (2013, 2018). They have helped us reframe our perspectives, widening our repertoires and looking at language issues from a socio-cultural-political perspective. Noteworthy here, for our analysis, is the interface between literacy scholarship and applied linguistics, 
which in Brazil is essentially an inter/transdisciplinary field focused on the impact of language in the world: it is far from being the application of linguistics, in that it brings forward a more political, embodied, relational and socially concerned approach to both languages and linguistics than the discipline of Linguistics alone (MOITA LOPES, 1996, 2006; JORDÃO, 2016; PEREIRA; ROCA, 2009).

The vignettes we present here are a composite not only of our direct experience, but also of tales of people who came to us after talks, in the corridors or informal conversations and research interviews to share personal experiences. After all, literacies are relational practices and our experiences are always built in such relationality.

\section{Vignettes}

VIGNETTE 1: Once upon a time there was an international group of researchers looking into various processes of internationalization of higher education all over the world. The group met yearly at different universities in order to exchange information and their local research results. Researchers collaborated on designing similar data generation instruments for their distinct realities and exchanged their data. From that data they established subgroups to focus on specificities of internationalization. One of these groups was in charge of looking into all the participant universities internationalization policies. Their report in one of the whole group meetings mentioned that some universities, all belonging to one same country, did not have any policy for internationalization. It seemed just natural to most people in the room, for such country was known as a rather messy place where such things were likely to happen since it was a young country compared to the others.

Stereotypes are part of the politics of representation, which in coloniality means the most powerful having the authority to speak for the powerless. It also means those with a voice representing the voiceless according to their own projections and interpretations of the voiceless. It can even mean representing those with less powerful voices as voiceless people themselves, forgetting all peoples have voices, only some are made silent or completely ignored.

As we have seen before in this text, representation also means, in the realm of coloniality, the colonizers projecting the colonized to the other side of the abyssal line, a metaphor used by Sousa Santos (2010) to refer to colonization. For him, the abyssal line represents the huge divide produced by the process of colonization that condemns the colonized to invisibility, to silence, to being nobody and producing nothing worth noting - to 
ontoepistemological inexistence. Unless, of course, the colonized emulate the colonizer ways. In other words, the only "salvation" to the conquistados would be to reproduce the ways of life, the values, the culture, the processes of meaning-making of the conquistadores, that is, to cease their own existence and to become their colonizers.

Our vignette 1 can be read as evidence of the pervasiveness of colonial difference even within a group of international scholars discussing internationalization from a critical stance, apparently willing to share their knowledges and learning from/with each other. The concept of language policy as a written document was conceived by those reporting their research as the only possibility for procedures to be understood as policies. Everything not belonging to this description was sent to the other side of the abyssal line and thus condemned to invisibility. In other words, practices unrelated to those avowedly homogeneous to the Global North were considered "nonpractices", delegitimized and silenced, if noticed as practices at all. A written document was understood as the only way to homogeneity, to a guarantee that everyone had access to the same procedures; a common curriculum, for example, is many times desired as an important step (if not a fundamental one) to internationalize education and assure quality across countries. The same applies to the purported need for a common language. Needless to say there is no guarantee when it comes to human beings: they are agentive, willful, localized, bound by enunciative situations (BAKHTIN, 2010) and very likely to surprise researchers, regardless of programs professing to follow one and the same curriculum.

When we examine higher education practices in various countries around the world (MACARO et al., 2018; DEARDEN, 2015), we notice that one move towards internationalization is pervasive in most institutions, especially in the Global South: the use of English as a Medium of Instruction (EMI), which seems to have been normalized as the main practice to determine if a university is or is not internationalizing. In many universities in Brazil, for example, EMI courses have been advanced as trustworthy indications that the university is (or is becoming) international (cf. MARTINEZ, 2015; BAUMVOL; SARMENTO, 2019).

The assumption that EMI may be taken as an indication of internationalization purports that there is something called EMI, and that this commodified object, or this reification of language, remains the same wherever it is taken. From such assumption, it becomes easier to understand 
how EMI becomes a token for internationalizing any university all over the world: understood as a homogenous and stable object, English is seen as something that can be quantified, measured and thus controlled. It is also, let us not forget, conceived as a "property" of certain powerful countries such as England and the U.S. These countries already have English as an asset. Seen as a sine qua non condition for internationalization, it somehow exempts countries seen as the home of English from fulfilling such condition. Besides, while many universities in the Global North seem to be able to afford to have EMI widely implemented in their programs, those in the Global South struggle to even understand why such condition should be met, when their reality can benefit very little from EMI at times: in Brazilian universities, for example, most international students come from our Spanish-speaking neighboring countries in Latin America (BRASIL, 2019) but still here the presence of EMI seems to be considered a strong indicator of the level of internationalization of higher education.

Internationalization of higher education has also manifested its colonial desire for homogeneity in another of its drives, alongside EMI: mobility. Studying abroad and attending international conferences in other countries have been almost synonymous with internationalization, at least in Brazil (JORDÃO et al., 2020; WIT, 2017). The exchanges abroad, so highly praised and very much craved by researchers (students and professors) often times are driven by the expectation of encountering similar practices and contents in similarly organized programs and disciplines to the ones we are familiar with: instead of opportunities to live difference and experience university practices otherwise, mobility is generally perceived as a way to acquire symbolic capital, or to either reinforce known practices, or even to make visible what is considered to be lacking in the institutions of origin as compared to those higher up in the world rankings. Some funding agencies even restrict the selection of partner universities based on perspectives such as these.

The formative role of higher education is therefore many times relegated to eventual collateral effects of the experience lived in a different institution. Instead, technical and instrumental education, transmissive and based on the possibility of "depositing" knowledge on students' heads (what Paulo Freire has critically called banking education - FREIRE, 1968) is often projected as the main reason why one should visit or study abroad. As a consequence, coloniality is reinforced and the flux is way more intense 
from the Global South to the Global North than vice-versa. When the main educational purpose of internationalizing is to "extract" content abroad to be applied back home, or to "extract" revenue from international students and scholars, one needs to privilege the highest ranked institutions for mobility. This perspective on how and why we relate with other peoples, countries, cultures, knowledges, ways of life and ways of knowing is certainly not restricted to higher education institutions, for such institutions are part of larger cultural, social, political and economical discourses that constitute contemporary worldviews guided by capitalism, colonialism, patriarchalism, globalization and neoliberal ideologies (SOUSA SANTOS, 2020).

VIGNETTE 2: Today is orientation day at an international university. A group of Brazilian bigh school teachers of English, visiting the university for a month, are assigned a freshman as their guide. He is anxious and eager to show them his new place of study. The teachers are walking on clouds for being at such a well-known university in the Global North. For most of them, this is their first time abroad. They all meet cheerfully and set on a nice walk on the campus. The student does not stick to showing the buildings: he tells tales of his own attachment to the institution and previous experiences in his education - he mentions his high school, the process of his application to enter this university, adding particular cultural elements to living at university in the United States. There are a lot of details about the fraternities and how students are chosen to join them, about the culture of sports as part of students' lives at university. In his enthusiasm, he accelerates his speech, uses slang and local language, as well as local references that do not mean anything to the visitors. The teachers get nervous and attribute their lack of understanding to low proficiency of English on their part. The discomfort only gets worse as time goes by. The end of the tour comes as a relief to those teachers, but a feeling of misplacement lingers on.

The discomfort felt by the Brazilian teachers in our second vignette is not unprecedented. It is not a novelty that these teachers were facing the challenges of "the non-native speaker impostorhood" (BERNAT, 2008). In studies about the impostor syndrome, Bernat explains language teachers deal with feelings of inauthenticity, fraudulence and inadequacy; not only related to their language performance, but also due to the belief that they "should be a language expert" of the non-native language they teach. From our perspective, we can extend this impostor syndrome analysis to ordinary people too, as well as to a variety of communicative circumstances in which we/they/teachers need to make meaning in a "non-native language". It is not unfounded that some people feel diminished, misplaced, uncomfortable or inadequate in language social practices in which it is believed there is a 
lack of language fluency, expertise and/or proficiency on the part of the "non-native speakers".

Different dimensions of this complexity could be highlighted to analyze and question how modernity and coloniality play a highly significant role in labeling, comparing, judging, and splitting people apart - the well-known us/them dichotomy. Modernity has been preaching that human beings are separated entities and rational subjects, who are able to communicate and to receive, exchange and produce knowledge separately from their bodies, background, life stories (GROSFOGUEL, 2013). This way knowledge and language exist without people, out there, in an independent form in the world. The consequence of detaching knowledge and language from bodies with history, background, previous experiences is the production of knowledge and language as things/objects to be acquired and mastered, and for this reason, there must be a correct and rational way of knowing something and becoming an expert in such knowledge.

In this sense, being a language expert and able to use a language successfully is related to the understanding of language as an entity, a system and/or an instrument external to the subjects, as we mentioned in the introduction. According to this assumption, individuals know languages, possess language knowledge, and are individually responsible for the meanings and ideas they convey - as if they were independent from each other and language and knowledge were just things available in the world to be acquired. We do not deny, though, that there is a system organizing and structuring the functions of a language; also we do not deny it is quite obvious language has an ideological dimension and people are responsible for the meanings and ideas they convey. What we are emphasizing indeed is the fact that language and knowledges are (human) creations/productions and do not exist out there without people, without a situated social practice in which decisions are/were made in order to systematize them, and that those decisions were taken by beings with bodies, constantly becoming (DELEUZE; GUATTARI, 1997) in the relations established in their existences.

From our vantage point, without taking into serious account that languages and knowledges are social practices produced by certain bodies in situated historical circumstances (HARAWAY, 1988), it becomes very hard to scrutinize the violences modernity has been imposing in the last centuries. Accepting divisions among the ones who know from the ones who do not know is accepting the reproduction of the abyssal lines and 
allowing coloniality to keep going hand-in-hand with modernity. As it is not any knowledge or any language that has value and social capital, one should recall that the languages and the knowledges expected to be acquired and mastered by the colonized are, in fact, what the colonizer knows and speaks. As Stroud (2015, p. 21) explains,

[t]he study of language was one of the Cartesian knowledge structures that undergirded the global project of subjugation, and remains a powerful tool of governmentality. Colonial linguistics crafted language as a technology for constraining and containing the diversity of others. Languages were described in speech forms indexically linked to identity and place in ways that sorted speakers hierarchically into categories of social class, ethnicity, and race. Processes of linguistic codification and translation construed local languages in terms of Western categories of thought and cut to the same cloth as metropolitan languages [...]. By determining what was 'sayable' within and across languages, processes such as these re-voiced the colonial other, silenced their histories and distorted their cosmologies.

Resuming the experience of the Brazilian teachers in our second vignette, one could notice how they were re-voiced and silenced based on feelings such as discomfort, inauthenticity, fraudulence and inadequacy. From the perspective of colonial difference and modernity, the teachers might see themselves, as well as be seen on the other side of the abyssal line, lacking language and knowledge. As a consequence, they find it very hard to interrupt the tour guide, to ask questions when they do not understand what he says, to ask him to repeat or rephrase, to suggest he uses less slang and local language, to express their own disappointment at not being familiar with the guide's cultural background, to share with the group they feel ashamed of not understanding what he is saying, and mainly to question the intercultural aspects that could be taken into account when one assumes the responsibility of guiding a visiting group of foreigners.

From the tour guide's standpoint, modernity and coloniality are also reinforced. It seems there is no need to be careful and thoughtful in regard to intercultural and ontoepistemological differences. The guide seems to be simply delivering his local knowledge without connecting it to the visiting group, or without allowing himself to transform his local knowledge while 
engaging with difference as his task is just to teach (or deliver, or transmit) and not to learn. His words sounded as if his local experience as a freshman in the U.S. were global, as if everyone would naturally know what a students' fraternity is and how the North American higher education system works, as if as if the Brazilians being the ones abroad naturally meant it was their responsibility alone to communicate effectively, and also their interest alone to learn from the Other. In sum, for the tour guide it seemed that, because the Brazilian group was visiting the U.S., they were the ones responsible for communicating effectively and learning about the Other.

This experience teaches us about the remaining division between us/them, the ones who know and the ones who do not know, the ones who speak the language and the ones who lack language. Assuming that someone lacks knowledge automatically leads us to consider that someone else does not lack such knowledge. This way, a comparative and hierarchical relationship is established among people on the premises that there is a thing called language and it can be reached in its totality. The experience also denies language as a social practice, constructed by people entangled in meaning-making. By accepting this division, one might believe that the ones who master the language know the language system, its structural functions, and are able to convey meanings correctly. In opposition, the ones lacking language and knowledge are unable to speak, understand or make meaning correctly. As a result, the understanding of language as a thing out there not only reinforces the perspective of language as an instrument used rationally, but mainly emphasizes language as an instrument of power which hierarchically separates people in abyssal lines.

This second vignette can also be analyzed from the point of view of internationalization. If one understands that language is an instrument and people should acquire it in order to benefit from the opportunities and privileges of internationalization in the global knowledge economy, one lacks intercultural attitude and misses the possibility internationalization entails to disrupt modernity/coloniality when ontoepistemological relationalities are taken into consideration. An international experience, whichever format it might be - including mobility, having contact with foreigners, taking an online course - requires the understanding and willingness to get in contact with ontoepistemological difference. As far as we understand it, language courses and mobility opportunities per se without a critical cultural dimension might reproduce the inequalities, racial and social hierarchies among people, 
as language and knowledge are out there, disembodied, and do not allow people to open up themselves for difference. An educational work which takes intercultural aspects into serious consideration could contribute to more horizontal relationships as it could teach people meaning-making is a reciprocal task, that we depend on each other to construct language and knowledge and that internationalization could allow us to engage with difference instead of sameness. Besides, if there is any room for difference, internationalization could promote critical awareness of social, ecological, historical problems, create spaces to challenge injustices and contribute to a debate about our planetary future.

VIGNETTE 3: A student from a Latin American country has been granted a scholarship in an agreement between a Brazilian Research Funding Agency and OAS (Organization of American States). She selects three universities in the south of Brazil as candidates for her PhD studies. One of these universities is considering her application and sends her research project to potential supervisors. Before even reading the ov of the student, one such supervisor reacts very negatively about receiving her. This professor claims that it is a great risk for the program to have someone who certainly lacks back.ground knowledge and has had a faulty education all her life. She adds that the student should be subjected to the same assessment procedures and entrance processes as Brazilian students.

While in vignettes 1 and 2 , the Brazilians could be seen in the position of the colonized or the Global South (in relation to a Global North), this positionality is inverted in our vignette 3 . Here, the international (Latin American) student is projected to the other side of the abyssal line, she supposedly lacks knowledge, background, language. The Brazilian professor, however, sees herself in the position of judging the student on behalf of the quality of the program, which positions the professor hierarchically above the student, on the visible side of the abyssal line. It's worth noting that the judgmental analysis made by the professor is prior to having met the student and based on the western understanding of background (mainstream, status quo, scientific) knowledge. Assuming the student lacks sufficient background experience, the professor shows the desire for sameness and the fear of difference as the knowledge the student has does not seem to be taken into account, on the contrary, the student's allegedly deficiencies are an issue of concern.

Once again, this dichotomic, judgmental, and oppositional relationality among peoples, countries, cultures shows how coloniality is ordinarily reproduced in our institutions and perpetuates racial and social 
inequalities. Unfortunately, this has been the logic informing educational discourses, policies and practices in the last decades and reinforced in internationalization; in the name of the quality and the advancement in education, people have been excluded and delegitimized. As we stated, the desire for sameness ends up justifying the field of education to be taken from the perspective of measurement and technicality which leads us to compare and rank people, schools, disciplines, knowledges, languages, cultures, institutions. In the case of our third vignette, instead of focusing on the formative benefits - that could be provided to the university, to the professor, to the international student, and also to local students in contact with an international student - the focus is on the instrumental knowledge of the student as well as the reinforcement of knowledge and language as objects.

From where we stand, quality in education and the logic of sameness are nothing else than the result of the two sides of the same coin: epistemic privilege and epistemic racism - a mental construction in which it is stated that some knowledges are superior and others are inferior in Western societies (SOUSA SANTOS, 2010; GROSFOGUEL, 2013). According to Grosfoguel (2013), all the epistemologies, the cosmologies as well as the worldviews that resulted from the colonial violences and genocides were considered inferior and turned into not legitimated knowledges. Even though the Brazilians in vignettes 1 and 2 were located in the other side of the abyssal line, the narrative in vignette 3 places Brazil as the Global North of Latin America. This inversion of positionality demonstrates the maintenance of a never-ending cycle of hierarchical relationships among people, places, institutions in internationalization practices in which modernity/coloniality is reproduced.

Our vignette 3 also allows us to consider another problematic aspect in internationalization: the juxtaposition of modernity, globalization and neoliberalism. Decades ago when we were not used to the term 'internationalization' yet, there was a predominant understanding that 'foreign' education could be seen as a form of aid around the world (MARGINSON et al., 2010). On the one hand, educational policies aimed at promoting and fostering academic, cultural, social and political ties between different countries and cultures by providing opportunities of exchange. On the other hand, young people from the Global North, mainly white and from middle/high social classes, were encouraged to join volunteering programs 
overseas based on the premise that their time, resources, and knowledges could be given away. In addition, scholars from the Global North were invited to teach in the Global South in order to spread the universal knowledge they had. Drawing on the assumption that some places and some people around the world are more civilized and owe a superior culture, the aid paradigm in education has informed many policies and practices of foreign and international education. Even though there was room for mutual learning and exchange, the common understanding was based on the fact that whoever occupies the Global South position is primitive and has to be taught and whoever occupies the Global North is civilized and able to teach.

More recently, with the impact of neoliberal globalization, the educational drive to internationalization has moved from aid to trade (MARGINSON et al., 2010) and while the charity perspective has decreased, the market-driven education has expanded its scope. According to Stein and Andreotti (2016), three dominant student recruitment practices take place in internationalization nowadays when Western higher education is positioned as a desirable product in the global knowledge economy. Students are seen: as a source of cash due to the tuition payments' system, as a source of competition in social mobility and employability, and as a source of charity as recipients of universal Western values and knowledge. As far as we understand it, either aid or trade, internationalization policies and practices unfortunately do not seem to consider the significance of ontoepistemological differences beyond modernity.

In the case of public universities in Brazil, we could question what premises have been informing academic recruitment and/or mobility. By looking at some of the latest programs, one could notice that international student mobility has demanded financial investments to send students from Global South to Global North (e.g. Science without Borders Program) ${ }^{2}$ and that there is a preference to agreements and partnerships with Global North institutions (e.g. CAPES Print). ${ }^{3}$ Also, it has shown resistance to receive students from Global South contexts by doubting their capacities and knowledges (e.g vignette 3). Still, educational programs informed by

\footnotetext{
${ }^{2}$ Available at: http://www.cienciasemfronteiras.gov.br/web/csf-eng/. Accessed on: Feb. 9, 2021.

3 Available at: http://www1.capes.gov.br/bolsas-e-auxilios-internacionais/capes-print. Accessed on: Feb. 9, 2021.
} 
charity values remain (e.g. the PEC-G initiative, ${ }^{4}$ an exchange program for students from developing countries to pursue their undergraduate studies in Brazilian higher educational institutions).

We are not saying, however, that these initiatives are worthless. We understand people engage, learn, share and always have the possibility of encountering difference in their contexts and experiences. We are highlighting how educational policies, practices and discourses have been informed by modernity and have been reproducing social disparities, epistemic racism and abyssal lines; as a consequence, we tend to reproduce and reinforce inequalities in our contexts and experiences. From where we stand, without taking the social responsibility higher education institutions hold in times of crisis as well as the impact of a neoliberal globalization in education, ontoepistemological differences are made invisible. It is with this concern we would like to conclude this paper.

\section{Final considerations}

While we write this paper, we are undergoing an unprecedented crisis highlighted by the global health pandemic of COVID-19, a crisis signaled by "the cascading effects of climate change and biodiversity loss, economic austerity and precarity, mental health crises, social fragmentation, right-wing political movements, large-scale human migration, and more" (STEIN, 2020, no page number). According to Stein (2020), there are those who respond to these crises hoping the system that caused them is restored and improved in order to avoid similar future crises. She, however, sees also another group of people who identify "the system itself as inherently harmful and unsustainable, and thus points to the limits of its reform, and ultimately seeks the emergence of a different system in its place." Along similar lines, Sousa Santos (2020) attributes the present COVID-19 crisis to the inequality, discrimination and selfism our capitalist way of life has created. He believes that we will only "overcome the quarantine of capitalism when we are able to imagine the planet as our shared house and Nature as our originary mother, to whom we owe love and respect. Nature does not belong to us. We belong to Nature" (SOUSA SANTOS, 2020, no page number).

${ }^{4}$ Available at: http://www.dce.mre.gov.br/en/PEC/PECG.php. Accessed on: Feb. 9, 2021. 
One might ask what role higher education plays in such a scenario of crisis: besides producing vaccines, developing technology to update medical and hospital equipment, devising treatments and helping follow the spread of the virus, which is already a lot, can universities do anything else to deal with the intrinsically unjust, excludent and violent system presented to us as the only alternative to organize our lives (SOUSA SANTOS, 2020)? On the one hand, the complicity of universities with coloniality still remains as modernity is the foundation of academic and scientific knowledge (GROSFOGUEL, 2013). On the other hand, we feel universities can still be privileged sites for problematization, for critical thinking and feeling, for (un)learning and being otherwise. As such, they offer us a space to imagine different futures and devise strategies to reach them; to evaluate the past and the present and to consider our position as human beings in relation to other forms of existence on the Planet. Universities, if arranged as multiversities (MATURANA, 2001) and therefore presenting and creating an ecology of knowledges (SOUSA SANTOS, 2019), may enable us to envisage new world orders integrating knowledges and ways of knowing for the construction of a world otherwise.

From our perspective, critical internationalization could play a crucial role in ensuring different institutions (universities and others) from radically different cultures make contact and learn from one another - not teaching, but learning together, collaboratively, within and without multiversities. Internationalization implies encountering praxes different from those we are familiar with; this means to engage agonistically with difference and refuse sameness. In this process, critical language/literacy education does contribute immensely to our mutual and self-learning, by making the heteroglossic realities explicit and our meaning-making practices concrete, visible and alive. The perspective of multiliteracies, more specifically, also helps "change the terms of the conversation" (MIGNOLO, 2007), as it moves us beyond the hierarchization of sciences that places humanities very low in the spectrum.

One might also ask what role literacy studies play in such a scenario of crisis. In fact, us being language educators situated in critical applied linguistics, linguistic education and literacy studies is precisely what made the analyses shared in this paper possible. Our background in language education has helped us face the challenges presented in the three vignettes from the perspective of language awareness, explicit positionality and a critical stance, 
three dimensions we see as directly related to our critical applied linguistics education. From where we stand, realizing the importance of languaging, literacies, subjectivity and interpretation to the construction of our worlds and knowledges, for example, means to value enunciative performativity as crucial to our meaning-making processes. The intersectionality of languages, nation-states, cultures, gender, class, subjectivity, together with the constructs of race and epistemic racism, are crucial in literacy scholarship: literacy, in our perspective, involves meaning-making practices, which are performative, localized, interrelational. Being aware of the multiplicity of literacy practices in ecologies of knowledges works for us as a motivation (even an imperative) to observe how different literacies and knowledges interact, conflate, and resist one another. Such awareness also pushes us to study the tensions that take place within difference, and how such tensions do constantly re-signify our practices. Instability, from our take on literacy practices, becomes a creative force that makes it possible for us to not only wish for, but also to act for the construction of a better world, and a better higher education that may be more inclusive, more open and always challenging.

\section{Agradecimentos}

Clarissa Menezes Jordão agradece ao Conselho Nacional de Pesquisa $(\mathrm{CNPq})$, pela bolsa de produtividade em pesquisa.

\section{Authors' Contribution}

As duas autoras contribuíram igualmente na elaboração e redação do texto, que foi escrito todo a quatro mãos.

\section{References}

BAKHTIN, M. Para uma filosofia do ato responsável. Trad. Valdemir Miotello e Carlos Alberto Faraco. São Carlos: Pedro \& João Editores, 2010.

BAUMVOL, L.; SARMENTO, S. Can the Use of English as a Medium of Instruction Promote a More Inclusive and Equitable Higher Education in Brazil? SFU Educational Review, Vancouver, v. 12, n. 2, p. 87-105, 2019. DOI: https://doi. org/10.21810/sfuer.v12i2.941 
BERNAT, E. Towards a Pedagogy of Empowerment: The Case of 'Impostor Syndrome' Among Pre-Service Non-Native Speaker Teachers in TESOL. ELTED Journal, [S.l.], v.11, p. 1-11, 2008.

BIESTA, G. Good Education in an Age of Measurement: On the Need to Reconnect with the Question of Purpose in Education. Educ Asse Eval Acc, [S.l.], v. 21, p. 33-46, 2009. DOI: https://doi.org/10.1007/s11092-008-9064-9

BRASIL Instituto Nacional de Estudos e Pesquisas Educacionais Anísio Teixeira (Inep). Censo da Educação Superior 2018: notas estatísticas. Brasília, 2019.

DEARDEN, J. English as a Medium of Instruction: A Growing Global Phenomenon. London: British Council, 2015.

DELEUZE, G.; GUATTARI, F. Mil Platôs: capitalismo e esquizofrenia. Tradução de Suely Rolnik. São Paulo: Ed. 54, 1997.

DUBOC, A. P. M.; FERRAZ, D. M. Reading Ourselves: Placing Critical Literacies in Contemporary Language Education. Revista Brasileira de Linguística Aplicada, Belo Horizonte, v. 18, n. 2, p. 227-254, 2018. DOI: https://doi.org/10.1590/19846398201812277

FREIRE, P. Pedagogia do oprimido. Rio de Janeiro: Paz e Terra, 1968.

GROSFOGUEL, R. The Structure of Knowledge in Westernized Universities: Epistemic Racism/Sexism and the Four Genocides/Epistemicides of the Long 16th Century. Human Architecture: Journal of the Sociology of Self-Knowledge, [S.l.], v. 11, n. 1, p. 73-90, 2013.

HARAWAY, D. Situated Knowledges: The Science Question in Feminism and the Privilege of Partial Perspective. Feminist Studies, College Park, MD, v. 14, n. 3, p. 575-599, Fall 1988. DOI: https://doi.org/10.2307/3178066

JORDÃO, C. M. (org.). Letramentos e multiletramentos no ensino de línguas e literaturas. Dossiê Revista X, Curitiba, v. 1, 2011.

JORDÃO, C. M. ILA - ILF - ILE - ILG: Quem dá conta? Revista Brasileira de Linguística Aplicada, Belo Horizonte, v. 14, n. 1, p. 13-40, 2014. DOI: https://doi. org/10.1590/S1984-63982014000100002

JORDÃO, C. M. Birds of Different Feathers: algumas diferenças entre letramento crítico, pedagogia crítica e abordagem comunicativa. In: TAKAKI, N. H.; MACIEL, R. F. (org.). Letramentos em Terra de Paulo Freire. Campinas: Pontes Editores, 2015. p. 195-208.

JORDÃO, C. M. (Org.). A linguística aplicada no Brasil: rumos e passagens. Campinas: Pontes Editores, 2016. 
JORDÃO, C. M. et al. Internacionalização em inglês: sobre esse tal de unstoppable train e de como abordar a sua locomotiva. Ñemityrã, Assunción, v. 1, n. 2, p. 30-43, 2020.

MACARO, E., CURLE, S., PUN, J., AN, J., DEARDEN, J. A Systematic Review of English Medium Instruction in Higher Education. Language Teaching, Cambridge, v. 51, n. 1, p. 36-76, 2018. DOI: https://doi. org/10.1017/S0261444817000350

MARGINSON, S.; NYLAND, C.; SAWIR, E.; FORBER-MEWET'T, H. International Student Security. Cambridge: Cambridge University Press, 2010. DOI: https://doi.org/10.1017/CBO9780511751011

MARTINEZ, R. English as Medium of Instruction (EMI) in Brazilian Higher Education: Challenges and Opportunities. In: FINARDI, K. (org.). English in Brazil: Views Policies and Programs. Londrina, EDUEL, 2015. p. 191-228.

MATURANA, U. A ontologia da realidade. Belo Horizonte: Editora da UFMG, 2001.

MENEZES DE SOUZA, L. M. T. Para uma redefinição de Letramento Crítico: conflito e produção de significação. In: MACIEL, R. F.; ARAÚJO, V. (org.). Formação de professores de linguas: ampliando perspectivas. São Paulo: Paco Editorial, 2011a. p. 128-140.

MENEZES DE SOUZA, L. M. T. O professor de inglês e os letramentos no século XXI: métodos ou ética? In: JORDÃO, C. M. et al. (org.). Formação "Desformatada": práticas com professores de língua inglesa. São Paulo: Pontes Editores, 2011b. p. 279-304.

MIGNOLO, W. D. Delinking. Cultural Studies, [S.l.], v. 21, n. 2, p. 449-514, 2007. DOI: https://doi.org/10.1080/09502380601162647

MOITA LOPES, L. P. (org.). Oficina de Linguistica Aplicada. Campinas: Mercado de Letras, 1996.

MOITA LOPES, L. P. (org.). Por uma Lingüistica Aplicada Indisciplinar. São Paulo: Parábola Editorial, 2006.

MONTE MÓR, W. Crítica e letramentos críticos: reflexões preliminares. In: ROCHA, C. H.; MACIEL, R. F. (org.). Lingua estrangeira e formação cidadã: por entre discursos e práticas. Ed. ampliada. Campinas: Pontes Editores, 2013. p. 31-50. (Coleção: Novas Perspectivas em Linguística Aplicada, v. 33). 
MONTE MÓR, W. Letramentos críticos e expansão de perspectivas: diálogos sobre práticas. In: JORDÃO, C. M.; MARTINEZ, J. Z.; MONTE MÓR, W. Letramentos em prática na formação inicial de professores de inglês. Campinas: Pontes Editores, 2018. p. 315-335.

PEREIRA, R.C.; ROCA, P. (org.). Linguistica Aplicada: um caminho com diferentes acessos. São Paulo: Contexto, 2009.

PRATT, M. Arts of the Contact Zone. Profession, New York, p. 33-40, 1991.

Sippin the EquiTEA. This 'Equity' picture is actually White Supremacy at work. Nov. 27, 2018. Available at: https://medium.com/@eec/this-equitypicture-is-actually-white-supremacy-at-work-59f4ea700509. Accessed on: Nov. 17, 2020.

SOUSA SANTOS, B. Para além do pensamento abissal: das linhas globais a uma ecologia dos saberes. In: SOUSA SANTOS, B; MENESES, M. P. (org.). Epistemologias do Sul. São Paulo: Cortez, 2010. p. 31-83.

SOUSA SANTOS, B. O fim do império cognitivo. Belo Horizonte: Autêntica, 2019.

SOUSA SANTOS, B. A cruelpedagogia do vírus. São Paulo: Editora Almedina, 2020. DOI: https://doi.org/10.2307/j.ctv1gm01nn

STEIN, S; ANDREOTTI, V. Cash, Competition, or Charity: International Students and the Global Imaginary. Higher Education: The International Journal of Higher Education Research, [S.l.], v. 72, n. 2, p. 225-239, 2016. DOI: https:/ / doi.org/10.1007/s10734-015-9949-8

STEIN, S. On the Possibility of Higher Education Otherwise, 2020. Available at: https://www.academia.edu/43988980/On_the_Possibility_ of_Higher_Education_Otherwise_May_2020_?email_work_card=viewpaper. Accessed on: Sep. 09, 2020.

STEIN, S.; ANDREOTTI, V.; SOUZA, L. M.; AHENAKEW, C.; SUSA, R. Who decides? In whose name? For whose benefit? Decoloniality and its discontents. On Education - Journal for Research and Debate, Zurich, Switzerland, v. 3, n. 7, s.p., 2020.

STROUD, C. Linguistic Citizenship as Utopia. Multilingual Margins, Western Cape, ZA v. 2, n. 2, p. 20-37, 2015. DOI: https://doi.org/10.14426/ $\mathrm{mm} . \mathrm{v} 2 \mathrm{i} 2.70$ 
THE BIBLE, N.T. And He Entered into a Boat, and Passed over and Came into His Own City. Matthew 9:17, 21 st Century King James Version. South Dakota: Deuel Enterprises, 1994.

WIT, H. de Global: Internationalization of Higher Education: Nine Misconceptions. In: MIHUT, G., ALTBACH, P. G., WIT, H. de (ed.). Understanding Higher Education Internationalization. Global Perspectives on Higher Education. Rotterdam: Sense Publishers, p. 9-12, 2017. DOI: https://doi.org/10.1007/978-94-6351-161-2_2

Data de submissão: 10/1/2021. Data de aprovação: 15/2/2021. 